industrial or commercial experience. But at least the unit is not to move to the NPL headquarters at Teddington in the near future - this would almost certainly be a mistake. It is true, of course, that the NPL Ship Division is nearby at Feltham, but there is not much sense in that either-Feltham is miles from a major centre of either shipping or of shipbuilding. To move the hovercraft unit to Feltham so that it could merge more closely with the ship division would be merely to pile one illogicality on another.

The hovercraft unit still operates from Hythe, on Southampton Water. The work it does is hardly pure research, but it is some way from direct commercial application. At present, studies are in progress on controllability and manoeuvrability and on improving fan propulsion systems. One of the principal research vessels, the HD 2 (see picture), contains innovations which make it, the unit says, the most controllable hovercraft in existence. This does not prevent it from travelling crabwise in a strong wind, but does enable it to do things like rotating rapidly on its own axis, or nosing up close to piers or to other vessels steaming along at full speed. The amount of spray produced is also a good deal less than earlier hovercraft, though it is not negligible.

The principal control system on the HD 2 is provided by two propellers, fore and aft, which can be swivelled through $\pm 35^{\circ}$. Naturally they are not quiet, but efforts have been made to reduce the noise level,

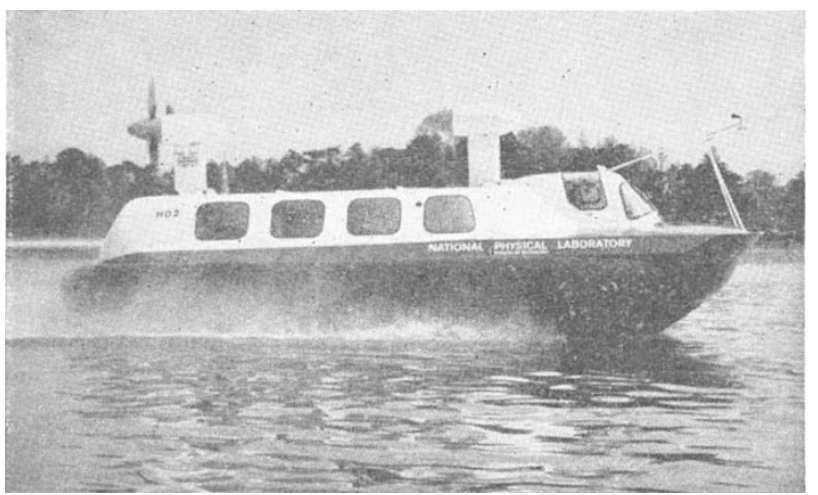

The HD 2 hovercraft.

and they are said to have been successful. The HD 2 also has what are called "puff ports" in the main material of the cushion. As their name suggests, these consist simply of holes which can be opened or closed to supply a sideways component to the vessel. There are four ports in the skirt loop, positioned at the ends of the straight side sections. If two on the same side are opened, the effect is to cause, or more likely correct, a sideways drift. If diagonally opposed ports are opened, the effect is to prevent the craft from yawing, that is pointing in a direction different to that in which it is travelling. To judge by the performance of the craft, the ports are not yet fully effective.

The final control system involves shifting the skirt, either sideways or fore and aft. The side sections of the skirt are connected by steel wires to a drive in the centre of the craft, and can be moved sideways by operating the right controls. The effect of this is to provide a few degrees of roll to the craft, originally intended as a means of preventing it from rolling in a strong sidewind. In practice the lateral skirt shift is more useful than this; when it is operated at high forward speed, it induces an asymmetrical drag, tending to turn the craft. Well balanced turns can therefore be made using this control alone.

The HD 2 also has a skirt with removable sections which can be replaced very quickly. There are 90 sections in the skirt, and each can be replaced by one man in about two minutes, with the hovercraft at rest. No jacking equipment is needed.

\section{Town and Gown}

Mr Nathan M. Pusey, president of Harvard University, has established a faculty committee to "examine Harvard's relations with its urban environment" in another attempt to forestall summer rioting in Cambridge, Massachusetts. A number of Harvard faculties are already working in this direction. There is, for example, the Education School's work in the predominantly Negro schools in Roxbury, but the new committee's aim is to study and coordinate these various programmes and, with luck, to sketch out the broader role Harvard should play in solving local urban problems.

The committee is chaired by James Q. Wilson, professor of government and an expert on American politics, and includes Professor Daniel P. Moynihan, director of the Joint Centre for Urban Studies and formerly a leading member of Robert Kennedy's brains trust. Its conclusions will be looked for with interest.

\section{Jobs for the Boys}

IN spite of Mr Anthony Wedgwood Benn's continuing distress over the brain drain, the fault seems to lie more with British industry than with British scientists. A recruitment programme run by Management Selection Ltd and sponsored by the Ministry of Technology has been overwhelmed with candidates working in United States industry and wishing to return to England. The problem is in finding British companies to employ them. P. D. Burnford, manager of the New York office of MSL since it was opened last September, does confess, however, that he is encouraged by the increasing interest on the part of British firms and is hopeful that several hundred applicants may be placed by the end of the first year.

As usual in any market, supply and demand do not match neatly. But at least the MSL scheme smooths the way to British jobs for those highly qualified applicants who would attract offers no matter on which side of the Atlantic they lived. As the programme becomes better known in the United States, the number of unsolicited applicants is growing rapidly. When specific openings in Britain are available, MSL tries to recruit candidates as it would in any country and arranges for especially promising men to be flown back to England for interviews. The men most in demand at the moment are electronics engineers, systems analysts, and business school graduates. $\mathrm{Mr}$ Burnford stressed that British industry's approach to this latter group has altered radically over the past two years; now any good British business school graduate will have a number of attractive offers from 
British firms, and at least a few of them match American offers.

On a somewhat higher and more specialized level, a new Scientists Appointment Service has been established by five British scientific institutions. It will attempt to register British scientists who are going to the United States under postdoctoral fellowships but who are intending to return to England to work. This information will be made available to any interested British firm and may ease some of the problems of transatlantic recruiting. At present, while British scientists in American universities are actively pursued by American firms, they only hear about British openings months after the posts have been filled. Since most of the scientists registered with SAS have good honours degrees and usually $\mathrm{PhDs}$ as well, they would have no problem finding jobs if they were in England; instead, the problems seem to lie in communication and education.

Education is needed for both potential employees and employers; the Royal Institute of Chemistry, which started a more limited programme 18 months ago, has found that many researchers look on industrial work as somehow inferior and will consider offers only as a last resort. On the other hand, many firms are suspicious of scientists returning from America, believing they will want too much money. When the Chemical Industries Association, at the request of the Royal Institute of Chemistry, sent out details of the original registering scheme to approximately 600 members, only about 50 companies were interested enough to reply.

It was this poor response from industry, in fact, that led the Royal Institute of Chemistry to approach four others-the Institute of Physics and the Physical Society, the Institute of Biology, the Institute of Mathematics and Its Applications, and the Institution of Metallurgists--in order to reach as many scientists and companies as possible. The Ministry of Technology also agreed to support the project with a $£ 10,000$ grant for the first year. After the inertia and lack of interest shown by the British companies approached by the Chemical Industries Association last year, the enlarged appointments service intends to spend most of its funds on advertising and promotional ideas to attract more firms. The service charges nothing until a firm has actually employed a scientist through its register; then the fee is $\mathfrak{£ l 0 0 .}$

\section{Progress of Nations}

THE Organization for Economic Cooperation and Development (OECD) has issued the annual accounts of its member countries from 1957 to 1966 (National Accounts Statistics, OECD, $£ 1 \cdot 875 / \$ 5 \cdot 5)$. The accounts would be even more interesting if accompanied by a chairman's report, but the OECD has perhaps wisely eschewed comment; the invidious comparisons are explicit enough in the figures themselves.

Japan has more than doubled her gross national product (GNP) since 1958, although her GNP per capita is still low compared with European countries (see table). Britain's GNP has risen by less than a third over the period, a rate of increase lower than any OECD country including Turkey. Although the percentage increase of GNP in the United States is not spectacular, the increase in absolute terms dwarfs
GROSS NATIONAL PRODUCT (MARKET PRICES) OF OECD COUNTRIES IN 1966

\begin{tabular}{|c|c|c|c|c|}
\hline & $\begin{array}{l}\text { GNP in } \\
\text { US } \\
\text { \$billion } \\
\text { (current } \\
\text { prices) }\end{array}$ & $\begin{array}{c}\text { GNP at } \\
1958 \\
\text { prices } \\
\text { (Index: } \\
1958 \\
=100 \text { ) }\end{array}$ & $\begin{array}{c}\text { GNP } \\
\text { per } \\
\text { capita } \\
\text { US } \$ \\
\text { (current } \\
\text { prices) }\end{array}$ & $\begin{array}{l}\text { GNP per } \\
\text { capita at } \\
\text { 1958 prices } \\
\text { (Index: } \\
1958 \\
=100 \text { ) }\end{array}$ \\
\hline Canada & $\mathbf{5 3 \cdot 5}$ & 147 & 2,670 & 125 \\
\hline United States & $756 \cdot 49$ & 146 & 3,840 & 129 \\
\hline Japan & $96 \cdot 42$ & 220 & 970 & 203 \\
\hline France & $102 \cdot 11$ & 151 & 2,070 & 136 \\
\hline Germany & $119 \cdot 62$ & 152 & 2,010 & 138 \\
\hline United Kingdom & $105 \cdot 05$ & 131 & 1,910 & 124 \\
\hline Austria & $10 \cdot 06$ & 142 & 1,380 & 136 \\
\hline Italy & $61 \cdot 49$ & 154 & 1,180 & 145 \\
\hline Switzerland & $14 \cdot 90$ & 151 & 2,480 & 131 \\
\hline Belgium & $18 \cdot 22$ & 143 & 1,910 & 135 \\
\hline Netherlands & $20 \cdot 77$ & 151 & 1,670 & 136 \\
\hline Turkey & $9 \cdot 42$ & 146 & 290 & 119 \\
\hline Denmark & $11 \cdot 14$ & 150 & 2,320 & 141 \\
\hline Norway & $7 \cdot 59$ & 147 & 2,020 & 138 \\
\hline Sweden & $21 \cdot 33$ & 143 & 2,730 & 136 \\
\hline OECD total & $1,447 \cdot 53$ & 149 & 2,160 & 136 \\
\hline OECD Europe & $541 \cdot 11$ & 147 & 1,530 & 135 \\
\hline EEC & $322 \cdot 91$ & 151 & 1,760 & 139 \\
\hline
\end{tabular}

that of any other country. Between 1965 and 1966 the US GNP rose by $\$ 61$ billion, an increment equal to the Italian GNP in 1966.

Italy devotes a smaller part of her GNP to research and development than almost any European country $(0 \cdot 3$ per cent in 1963 as against $2 \cdot 3$ per cent for the UK and 3.4 per cent for the USA) and her bill for patents and licences is correspondingly great; despite this, her GNP has risen faster than any OECD country but Japan. Rewards for virtue do not seem to obey the usual indicators of technological development, which suggests that the indicators are too crude or too incomplete.

The national accounts for each country are displayed both in absolute form and in index form with 1958 as a base. In Britain the components of GNP have risen at a rather uniform rate-consumer expenditure to 128 $(1958=100)$, government expenditure to 122 , exports to 132 and imports to 139 -despite the fact that capital investment has risen 61 per cent since 1958. Italy, with a capital investment increase of only 45 per cent, has raised consumer expenditure to 152 , government expenditure to 140 and exports and imports to 298 and 275, respectively, over the same period. Capital investment increases for other countries have been United States 146, Japan 284, France 175 and Germany 189.

Standard of living as judged by the per capita GNP (though this ignores the effect of taxes and the social services) is more than twice as high in the US as in Europe as a whole (see table). Sweden, however, comes second in this league table, followed closely by Canada and Switzerland.

\section{Coordinating Cancer Research}

A NEW organization-the British Cancer Council-has been set up under the presidency of Professor Sir John Bruce of Edinburgh to act as an advisory body at national and international levels, to promote the inter- 